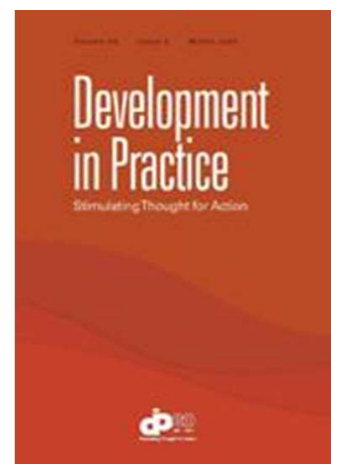

\title{
Women, Work and Wage Equity in Agricultural Labour in Saiss, Morocco
}

\begin{tabular}{|r|l|}
\hline Journal: & Development in Practice \\
\hline Manuscript ID & Draft \\
\hline Manuscript Type: & Article \\
\hline Keywords: & $\begin{array}{l}\text { Gender and diversity, Agriculture < Environment (built and natural), } \\
\text { Labour and livelihoods, Rights, Region: Arab States }\end{array}$ \\
\hline Abstract: & $\begin{array}{l}\text { This paper documents wages and working conditions for landless female } \\
\text { and male agricultural labourers in the Saiss region of northern Morocco. } \\
\text { We found that higher-paid equipment-intensive tasks were predominantly } \\
\text { assigned to men whereas women were almost always employed to perform } \\
\text { lower-paid, time-intensive tasks. Enforcing legislation that already exists in } \\
\text { Morocco to ensure equal pay for women is an essential first step towards } \\
\text { enabling women to benefit equitably with men from their agricultural } \\
\text { labour contributions. A deeper more global revalorization of the importance } \\
\text { of agriculture is also necessary so that agricultural labour is not perceived } \\
\text { as an occupation of last resort. }\end{array}$ \\
\hline
\end{tabular}

\section{SCHOLARONE" \\ Manuscripts}




\title{
Women, Work and Wage Equity in Agricultural Labour in Saiss, Morocco
}

\author{
This paper documents wages and working conditions for landless female and male \\ agricultural labourers in the Saiss region of northern Morocco. We found that higher- \\ paid equipment-intensive tasks were predominantly assigned to men whereas women \\ were almost always employed to perform lower-paid, time-intensive tasks. Enforcing \\ legislation that already exists in Morocco to ensure equal pay for women is an essential \\ first step towards enabling women to benefit equitably with men from their agricultural \\ labour contributions. A deeper more global revalorization of the importance of \\ agriculture is also necessary so that agricultural labour is not perceived as an \\ occupation of last resort.
}

Keywords: Women, work, wage equity, gender norms, agriculture, Morocco, Arab States, Saiss

\section{Introduction}

This research investigates and assesses how opportunities and constraints related to wages, working conditions, and sociocultural norms interact to shape the experiences of female and male agricultural labourers working under different terms and conditions (family-owned and commercial farms, rain-fed and irrigated areas, and various crop types) in the agricultural sector of Saiss, Morocco. Since their labour is the most important asset the landless poor in general, and women in particular, have to offer, it is critical that we pay attention to improving wages and working conditions (Razavi 2007). Women increasingly perform a majority of agricultural work in many world regional contexts, including the Arab States, but are almost always paid less than men and experience more precarious working conditions (Abdelali-Martini 2011). Current research on agricultural labour in the Arab States focuses primarily on how internal and international migration, mainly of men, has affected the daily activities of women left behind and their influence on household decision-making effects (see, for example, de Haas and Van Rooij 2010). Any reference to working conditions and 
wage work for women in rural areas is treated as secondary in importance to male outmigration and its effects upon women. Abdelali-Martini et al. (2003) does note that low wages in the agricultural wage sector are drawing men out into non-agricultural work and that women are increasingly replacing men in the agricultural sector. Razavi (2007) takes it further by emphasizing that women have become the majority of the agricultural labour force in various locations in the Global South primarily because they have low bargaining power and are willing to work in the sector despite low pay and poor working conditions. She notes that in many parts of the Global South, the commercialization of agriculture is in fact purposively predicated on cheap female labour:

"Corporate farms use a gender-segregated workforce, within which women are overwhelmingly employed in more insecure, less well paid and lower skilled activities, without opportunities for advancement. The work is very often seasonal, with long hours of work, poor health and safety conditions and no social protection.” (Razavi 2007, 1495)

The general gender wage gap in the Arab States has never been systematically explored or documented. Precise data on wages earned by women in agriculture is even harder to find. A meta-analysis of the international gender wage gap conducted by Weichselbaumer and Winter-Ebmer (2005) emphasised that the data gaps for the Arab States are particularly glaring and that countries in this region would benefit from systematic data collection on key human capital factors such as gender discrimination in wages.

Through primary research conducted in Saiss, Morocco, this paper contributes to the literature on gendered inequity in wages and working conditions in the agricultural sector. Our study includes agricultural wage work for men and women both in areas that experience male outmigration as well as in receiving communities that experience in-migration. This is also a distinct contribution of our research. 
We begin this paper with background literature on gender and agricultural work in Morocco and other Arab Countries as well as relevant contextual information about the specific areas in which our fieldwork was conducted. Then we present findings from our empirical research on wages and working conditions for 415 agricultural wage labourers (187 women and 228 men) in Saiss, Morocco. We describe problems experienced by workers as well as solutions proposed by them. We conclude the paper with recommendations for improving wages and working conditions for agricultural labourers.

\section{Background Information on Agriculture in Morocco and the Case Study Areas in Saiss}

Agriculture, in general, and wheat production, in particular, plays an important role in the Moroccan economy. With a total area of 3.2 million hectares dedicated to growing wheat and production of about seven million tons in 2013 , wheat is the single most dominant crop in the country (FAO 2016). In areas where water availability is adequate year round, onions, potatoes, and fruit are also grown. Both onions and potatoes are among the top ten commodities by quantity produced in Morocco, with potatoes at third place and onions at tenth place (FAO 2016). Processed fruit ranks fifth among the top ten export commodities by quantity in Morocco (Ibid.).

Employment in agriculture in Morocco has grown dramatically in the past 30 years and so has the contribution made to the sector by female agricultural labour (Assaad 2004). The State of Food and Agriculture (SOFA) report produced by the Food and Agricultural Organization (FAO) in 2011 shows a sharp increase in Morocco in female employment in agriculture from $29 \%$ in 1980 to $38.9 \%$ in 1995 to $47.7 \%$ in 2010 , while men's contribution to agriculture has decreased considerably from 66 to 55\% between 1995 to 2011(AbdelaliMartini 2011). Very similar trends of feminization of agriculture - defined as women representing a majority share of agricultural labour, but typically at lower wages and more 
precarious working conditions than men - have also been reported in Algeria, Jordan, Syria, Libya, Palestine, and Egypt (Ibid.). In Morocco, the dramatic growth in employment in agriculture may be attributable to the investments made by the Moroccan government in agriculture and food security through, for example, subsidies for irrigation, during this period. The privatization of land in 2005 in the Saiss region may also have contributed to the rapid adoption of innovations (such as wells and drip irrigation) that led to increased cultivation of cash crops (Bossenbroek et al. 2015).

There are other factors that may also have contributed to the dramatic increase in female employment in agriculture in Morocco and other Arab States. For example, AbdelaliMartini et al. (2003) notes, while writing about Syria, that rural agricultural land has been fragmented primarily because of inheritance. In turn, because small landholdings cannot adequately support the needs of families, men frequently migrate to cities in order to earn higher wages, and women become responsible for agriculture, which has become more labour-intensive with the intensification of agriculture resulting from increased irrigation. Due to male outmigration in Egypt and Morocco, women increasingly work on their own land and/or as labourers on land owned by others (de Haas and Van Rooij 2010).

These general trends appear to apply well to our case study areas in Saiss. Land privatization, combined with the loss of common pasture land and drought in neighboring areas, has fueled landlessness and migration in some areas (the community of Ain Jemaa in our study is a good example), and created a surge in female and male agricultural labour in more productive agricultural areas (the communities of Betit and Sidi Slimane are good examples) (Figure 1). Speaking more broadly about Morocco, Davis (2006) describes how an alarmist colonial environmental narrative about overgrazing and pasture damage in the dry agricultural lands has been resurrected by the Moroccan government and international financial institutions to help justify and implement neoliberal goals of land privatization and 
the intensification of agricultural production in the name of economic growth and environmental protection.

Insert Figure 1 about here.

The three areas of the Saiss region in Morocco included in this study were Ain Jemaa, Betit and Sidi Slimane. These areas differ in terms of natural resource endowments and labour markets. Ain Jemaa is rain-fed, typically grows subsistence food crops such as wheat, chickpeas, fava beans, and olives. Sunflower is also grown as an oil crop. Most agricultural work is carried out by family labour. Demand for paid agricultural labour is relatively low, but often a little higher during planting, weeding and harvesting seasons. The other two areas, namely, Betit and Sidi Slimane, have in recent years, owing to the Green Morocco Plan (GMP), received extensive irrigation infrastructure making more commercial cultivation feasible. The GMP offers grants to cultivators for drip irrigation and wells at highly subsidised rates as noted in an Al-Monitor article on October 12, 2014. The average landholding size in Ain Jemaa is much bigger than it is in Betit and Sidi Slimane but land has been cultivated more intensively, owing to availability of irrigation, in the latter areas.

Because of the year-round availability of water in Betit and Sidi Slimane, there is both a higher demand for more water-intensive crops such as onions, potatoes and fruit frees as well as a higher need for hired agricultural labour. Agricultural wages are also significantly higher in these two areas than in Ain Jemaa. For these reasons, labourers from the rain-fed areas, including women, migrate in large numbers to Betit and Sidi Slimane. Some women may accompany their husbands or parents, who often work in agricultural and nonagricultural activities, to the irrigated areas. Other women - typically single, divorced, widowed, separated, or married women whose husbands live away from their families migrate to Betit and Sidi Slimane as de jure or de facto heads of households. In these irrigated areas, onions and potatoes are particularly labour-intensive crops and even family- 
owned farms and smallholders require hired additional labour especially during planting and harvesting. As opposed to Betit, where the majority of farmed areas are owned by smallholders, Sidi Slimane's agricultural landscape is dominated by larger commercial farms. Zneibar and Ameera are two commercial farms in Sidi Slimane that were included in this research. Commercial farms typically specialise in fruit tree production.

\section{Methodology}

The empirical data for this study were collected through a survey administered to 415 labourers (187 women and $228 \mathrm{men}$ ) in the Saiss region of Morocco during November and December 2014. As mentioned previously, the surveys were conducted in the districts of Ain Jemaa, Betit, and Sidi Slimane because they differ significantly in biophysical characteristics and agricultural dynamics. They also differ in gender norms and levels of economic development. There are fewer opportunities for wage work in Ain Jemaa than in the other two communities. Labourers were sampled from all three communities as follows: 29 in Ain Jemaa, 144 in Betit and 242 in Sidi Slimane (see Table 1 for gender and age groups).

The survey data was complemented with a total of 36 semi-structured interviews with labourers aimed at understanding issues related to wages and working conditions in paid agricultural labour (11 in Ain Jemaa, 13 in Betit, and12 in Sidi Slimane) conducted in 2014 and 2015. The interviews conducted earlier in 2014 provided baseline information for designing the survey questions administered later the same year; the interviews conducted in 2015 helped us better understand and contextualise findings from the 2014 survey. Initial interviews conducted in 2014 revealed that agricultural work was almost non-existent during the winter and labourers endured financial hardships during this time of the year. In the survey conducted later in the same (2014) year, we incorporated questions aimed at 
understanding how labourers cope with such financial hardships, and whether the coping mechanisms differed between men and women.

We also conducted six gender-segregated focus groups (two in each of the three case study areas) in 2015. Each focus group included 8-10 men or women. The focus groups were aimed at understanding local perceptions and social norms regarding male and female agricultural wage work in the three communities. The focus groups and interviews mentioned previously helped further validate, contextualise and strengthen survey findings with qualitative examples and ethnographic detail. Triangulation - validation from multiple sources - was employed to analyze qualitative findings.

Six men and six women - all fluent Arabic speakers with strong backgrounds in social science and experience with data collection - administered this survey. The female enumerators surveyed women, and the male enumerators surveyed men. The enumerators were instructed not just to ensure that women represented $50 \%$ of the survey participants but also to ensure that diverse terms and types of employment (daily wage labourers, monthly wage labourers, workers employed in small, medium, and large farms) were represented in the survey. Enumerators were also asked to ensure diversity in age groups of respondents so that both youth (below the age of 24) and adult workers were included. Each survey took between 30 and 40 minutes to complete. The survey was designed to elicit information about wage differences based on gender, age and communities; types of agricultural tasks assigned to men and women as well as the underlying rationale; and differences in gender norms in the three case study communities. Additionally, questions were designed to identify problems faced by men and women in agricultural work as well as their suggestions for solutions.

Finally, in 2015 we also conducted six interviews (two from each case study community) with labour supervisors who are themselves labourers but are also responsible for hiring and supervising other labourers. We hoped that understanding their perspectives 
about wages and working conditions would add an additional layer of nuance and complexity to our findings since our other research participants were exclusively labourers.

Enumerators used a snowballing technique, where each person who participated in the survey identifies other potential survey participants. Some surveys were carried out while respondents were working; others were interviewed in their homes. Survey respondents were not compensated for participating in this study. Although women represent more than $50 \%$ of the agricultural labour force in Morocco, interviewing them was often more challenging since women tend not to spend much time in public spaces such as streets or coffee shops, which enumerators and interviewers, especially if they are men, can more easily access. Men were surveyed and interviewed more often in these public venues, while women were sought out at work or in their homes by female enumerators. This strategy seemed to work well for our study in Morocco and for other studies with women farmers or agricultural labourers in the Arab States (see, for example, Galie 2013, for research on female farmers in rural Syria). Surveys were analyzed using STATA, SPSS and Excel software.

Table 1 about here.

\section{Findings}

We organised findings generated from the surveys, focus groups, and interviews by describing the wages received by women and men, the respective tasks they are assigned, and the underlying gender norms and assumptions that influence those decisions. We also include data in this section about the seasonality of tasks, the different types of farms, group dynamics, problems faced at work and solutions proposed by the labourers. The final section of findings examines how male and female wage labourers experience and cope with financial hardships. 


\section{Wages and tasks}

The average daily wages reported by men and women reveal that there is a gap of about 10 dirhams (each 10 dirhams are equivalent to about one US\$) or 16\% in favor of men. The tasks that generate the highest labour demand are harvesting, weeding, planting, and seeding (see Table 2). Although both men and women perform these tasks, women tend to be preferred. When asked why women are preferentially hired for these activities, both and female labourers responded that although these tasks required significant manual labour, they were easy to learn and not overly strenuous. They further emphasised that because these tasks were understood to be laborious but not require much physical strength, it was also possible to pay less to get them done.

Almost twice as many women as men worked in weeding, thinning, packing, grafting and sorting onions. These tasks require longer periods of time to complete and are perceived to require both patience and "nimble fingers" - gender essentialisms assumed to characterise women more often than men (see, for example, Mills 2003). A combination of these assumptions and women's greater willingness (borne at least partially of a lack of options) to work for lower wages motivated employers to hire women more often for these tasks. While men were paid 70 dirhams on average per day for packing and weeding across crops, women were paid 50-60 dirhams. The most pronounced gender wage gap in harvesting (70 dirhams for men versus 50 for women) was for olives. While men used sticks and machines to harvest olives, women collected olives from the ground.

When all agricultural tasks required to produce a single crop are considered, wheat had the largest crop-specific wage gap between men and women. Women were almost exclusively hired for cleaning wheat while men were hired for a range of different activities. Women earned 20-25 dirhams per bag for cleaning wheat while men were paid between 70 and 200 dirhams for tasks such as spraying, harvesting, and weeding. 
Although far more women are employed in packing of fruits and vegetables, individual interviews with employers revealed that for every 10 women packing onions, two to three men were hired to carry boxes. These male labourers both packed onions and carried the boxes to the trucks. Similarly, fruit harvesting requires that men are also hired in order to carry boxes. Men were paid more because they were also expected to carry boxes of fruits and vegetables to the trucks. Men were paid 120 dirhams per day for packing and carrying the boxes, while women were paid 80 dirhams per day. It was unanimously assumed that women would be unable and/or unwilling to carry boxes.

Men were also paid more for planting and related activities. For example, for transplanting onions from the nursery, women or children were paid 50 dirhams. Men, on the other hand, were paid 70 dirhams for the same task.

There were striking differences in the three communities in the responses about the social acceptability of women's paid work in agriculture. Both male and female respondents in Ain Jemaa identified permission from husbands, working in sex-segregated groups, and proximity to home as important criteria for socially-acceptable agricultural work for women. In Betit and Sidi Slimane, on the other hand, respondents did not seem to have any issues with women working in groups that also included men, nor with having to work in farms that were not close to their homes. These responses seem to suggest that there are more labour opportunities for women in Betit and Sidi Slimane and more social control (see Lapham 1969 for a definition) over women's labour in Ain Jemaa. It is difficult to state the latter convincingly, though, since the restrictions placed upon women's labour in Ain Jemaa may be more indicative of the lack of adequate agricultural work for men rather than social control based on cultural norms. The cultural norms themselves may have evolved as a function of scarcity in Ain Jemaa - to protect available work for men. Some poor women in Ain Jemaa did complain that only men get work in the area; women have very few opportunities for paid 
work close to their homes. As a result, some of these women, especially widowed, divorced, and deserted women, migrate to the neighboring communities of Betit and Sidi Slimane, where agricultural work is both more acceptable and available for women. Nonetheless, we found that there was a degree of social control over women's participation in agricultural labour even in Sidi Slimane and Betit. Focus groups with women labourers in the latter areas revealed that their husbands forbade them from working on large farms because of potential contact with other men. They were often restricted to working on farms in which the husbands personally knew the owners.

Irrigation, fertilizer and pesticide application, and supervision of labour are predominantly performed by men and earn more by an average of 20 dirhams than the tasks which predominantly involve women. The gender wage gap between tasks dominated by women and tasks dominated by men is on average about $25 \%$. More men than women participated in planting and seeding various crops. Planting, seeding, and fertilizing were considered laborious tasks that also require tamara or physical strength, and men were always selected to perform them. Some of the planting and seeding activities were mechanised and did not actually require any physical strength to perform but only men were deemed able to operate the seeders and tractors. Similarly, applying pesticides requires operating machinery in the form of spray backpacks or tank sprayers. Male labourers were paid between 100 and 200 dirhams per day to perform planting, seeding and spraying. In addition to operating machinery, spraying also required access to information about the appropriate doses of pesticide application. Since spraying was considered a male task, information about pesticide doses was also exclusively available to men. Irrigation and pruning are also largely dominated by men. Pruning is considered a skill-intensive task, which typically only men acquire while growing up on or around farms. Irrigation activities are typically carried out at night and exclusively by men. Abdelali-Martini (2011) reports that 
women are similarly excluded from irrigation work in Iran both because it is classified as a nocturnal activity and because cultural norms prevent women from interacting with unrelated men.

Laborious and skilled tasks performed by women - such as thinning, which required the use of scissors, and archage (the bending of trees so that the sap can reach the fruits more efficiently) - were paid at least 20 dirhams less than labour - and skill-intensive tasks performed by men. Women are paid 80 dirhams per day while men earn 100-120 dirhams.

The highest wage recorded for women (240 dirhams per day) was for sorting onions. Based on the appearance of the onions, sorters have to make decisions about which bulbs are rotten and which ones are not and, therefore, have a longer shelf life. The comparably high pay for this task can probably be attributed to its urgency and time-sensitivity. Women also sort potatoes but are paid only 70 dirhams per day for this task, presumably because potatoes in general tend to have a longer shelf life than onions.

Insert Table 2 about here.

Young labourers (those under the age of 24) comprise a significant portion (16\%) of participants in this study. Since youth face significantly higher levels of unemployment and also migrate from rural to urban areas more frequently than other age groups (Bossenbroek et al. 2015), we paid close attention to specific employment opportunities and constraints facing young agricultural workers in our study. We found the gender wage gap for young workers to be slightly more pronounced than for adult female and male workers. There is a gender wage gap of about 12 dirhams on average for respondents below the age of 24 , and a gender wage gap of about 10 dirhams for respondents above 24 (see Figure 2). The highest general wages were reported for the 26-35 age group for both men and women and the lowest for the 56-65 age group (see Figure 3). This suggests that there is greater need for social protection for labourers above the age of 55. 
Insert Figure 2 about here.

Insert Figure 3 about here.

It is important to understand the age distribution of the respondents as well as agespecific opportunities and constraints in more detail. There are more men than women in the agricultural labour force in the lower age groups. This seems to suggest that boys are much more likely to enter agricultural work at a younger age. Indeed, when the 415 respondents were asked at what age they started working in the agricultural wage sector, men reported a younger age (Figure 4). Of the three research locations, men in Ain Jemaa reported the earliest age of entry for male workers while women in Betit reported the earliest age of entry into agricultural labour for female workers. Work opportunities in Betit are typically on local farms whereas in Sidi Slimane they are more often on larger commercial farms. Women are often discouraged from working on commercial farms because they are assumed to be more vulnerable to sexual harassment and exploitation in such environments. Since most of work available for women in Betit is on local farms and since there is also higher social acceptance in that community for women's involvement in paid agricultural labour, women are more likely to enter agricultural work at an earlier age in Betit.

It was difficult to gauge why there were twice as many men as women in the 26-35 age. The most plausible, and most often repeated, explanation we were offered during focus groups and interviews is that women are reluctant to work in agricultural wage labour due to real or assumed fear of sexual harassment and consequent reputational damage. Especially if they are young and attractive, women workers are reported to be subjected to sexual harassment by labour lords and asked for sexual favours, especially on commercial farms. Many women are forced to tolerate aspersions about their character as well as misbehavior from labour lords on big farms because work is more frequently available for them on such farms and the pay is better than on family-owned and small farms. 
While young workers (below the age of 24 ) represented only $16 \%$ of the sample in our study, the 36-45 age group dominated the survey accounting for about $33 \%$ of total respondents. Although young workers are by no means marginal in agriculture, their share of the agricultural workforce is small compared to adult workers. It is possible that either young workers are not particularly attracted to agricultural labour (Bossenbroek 2015 discuses young people's ambivalence towards agriculture in Saiss), or that more adult workers, especially women, take on agricultural work in larger numbers either out of choice or necessity.

\section{Insert Figure 4 about here.}

Both the average pay and gender wage gap were the worst for workers in Ain Jemaa (Figure 5). At community level, the wage gap is 12.07, 11.09, and 9.9 dirham per day in Ain Jemaa, Betit and Sidi Slimane, respectively. This translates to $24 \%, 17 \%$ and $15 \%$ higher wage for men in Ain Jemaa, Betit and Sidi Slimane, respectively.

Both Sidi Slimane and Betit have lower levels of task assignment by gender, almost all $(86 \%)$ of the tasks are performed by both men and women. Aim Jemaa has a higher level of gender-based segregation of agricultural work: about $64 \%$ of tasks were performed by both men and women while $36 \%$ were assigned exclusively to either men or women. Overall, women perform $33 \%$ of agricultural work in Ain Jemaa, much lower than the other two communities where women perform $37-58 \%$ of agricultural work.

Insert Figure 5 about here.

\section{Seasonality of work and working conditions}

This section explores the seasonality of wage work, the bargaining power of men and women, labour group dynamics, sources of information about agricultural work opportunities, the most desirable types of work, and how farm type affects working conditions. The most commonly reported type of wage work is seasonal labour hired during the peak planting and 
harvesting season from August to November in Betit and Sidi Slimane. In Ain Jemaa the main agricultural tasks generating paid employment are the harvesting of olive trees during November and weeding in April and May. Labourers from Ain Jemaa will often travel to Betit and Sidi Slimane to take advantage of the peak labour period there.

There are three types of workers at Zneibar, which is one of the largest commercial farms producing wine in Morocco: the permanent formal worker, the permanent informal worker, and the seasonal worker. Equal numbers of men and women are employed in the permanent formal category. Men work as guards and irrigators while women work in 'frigo' storing fruits in large refrigerators. Although, this constitutes a small portion of the total labour pool at Zneibar, this group gains access to benefits such as health care and pensions. Then there is the permanent but informal category. This group works on farms year round but is let go every six months for two weeks so that the employer can avoid hiring workers on a formal basis. The third and most common type of employment is seasonal. Labourers are hired on a 15-day basis. Even workers who hold formal and permanent jobs typically started out as seasonal labourers. As in many other agricultural settings in the Arab States (see, for example, Abdelali-Martini 2011) workers on Zneibar farms work in sex-segregated groups, ostensibly to protect women from harassment.

Women are more likely to be hired occasionally and informally. The tasks most commonly performed by women tend to be carried out during the peak season. During the low labour-demand season, from December to February, most of the jobs available involve plowing, pruning, irrigating and fertilizing the land, which, as mentioned earlier, are performed predominantly by men. Therefore, women are more likely to experience a severe lean period in the winter. Harvesting olives is one of the few tasks available to women in the winter. However, the pay is $10-15$ dirhams lower than other harvesting tasks - due both to surplus labour availability and lower labour needs during this time. 
Other large farms also employ permanent labourers to irrigate, guard the land and supervise seasonal labourers but employment tends to be informal. A 50-hectare farm, for example, requires six guards and two irrigators (one for daytime hours and another for the night) but this type of work employs a small number of exclusively male workers. The monthly wage ranges between 1300 and 2100 dirhams. Most seasonal non-urgent work is paid a daily wage. Planting and harvesting tasks on smallholder farms is done attache or per task. Labourers often preferred this type of work as they were paid 150-200 dirhams per day versus 60-100 dirhams per day during the non-peak season and on large farms. Despite the lower pay, both male and female workers on large farms are hired for longer periods of time (two weeks at a time) because the areas being cultivated are larger. However, on bigger farms we found that women are often paid less than men (by 10 dirhams on average) even for the same tasks. Both male and female labourers reported that employers always assume that men are more efficient and faster than women and therefore pay men more even for the same tasks. Other labourers reported that women were more obedient and hardworking, whereas men took frequent smoke breaks and were more likely to protest for higher wages and better working conditions. This certainly resonates with Razavi's (2007) assertion that the commercialization of agriculture in many parts of the Global South has been predicated on cheap and docile female labour.

Bigger farms predominantly produce fruit and the pay is lower. Onions and potatoes, which are typically grown on smallholder farms, require a surge of time-sensitive labour and tend to pay more. Although the pay is higher on small farms, the gender wage gap is also higher and reaches up to 20 dirhams even for the same tasks. Often women are also not compensated adequately and recognised for the tasks that they end up performing. For example, many women interviewed explained that although men are paid about 20 dirhams more for carrying boxes during harvesting season, women also carry boxes so that the task 
can be accomplished as quickly and efficiently as possible. Yet women are paid 20 dirhams less since men are assumed to be carrying the boxes.

When asked whether they had a favorite task, $38 \%$ of the women and $22 \%$ of the men respondents confirmed that they had no favorite tasks, and that their employment in the agricultural wage sector is simply an option of last resort. Both male and female respondents considered the work exhausting and unstable and the payments low.

Other labourers did express preferences. The three tasks most preferred by men were seeding, planting and harvesting, all three also reported to be better paid. Harvesting was additionally deemed an easier task. Women's most preferred tasks were packing, harvesting and preparing cuttings for grafting since they paid well and were easier to complete. Weeding was identified as a preferred task by both men and women because it was available throughout the year. Women identified onion as the crop they liked best because they could complete work early and leave for home to attend to domestic chores. Onion planting and harvesting were preferred tasks because payment is contingent on completing the task at hand rather than committing to work for the entire day. The pressure women in general, and lowincome women in particular, face juggling remunerative and reproductive responsibilities has, of course, been documented by researchers in many global settings. Women working in the agricultural sector in Saiss are clearly no exception.

During the time of the survey in 2014-2015, working hours for daily wage workers was from eight am to three pm. Before 2011, working hours were from eight am to five pm. Both male and female labourers in the mawqif (a gathering area for labourers or a labour mart) protested the working hours in 2011 and succeeded in getting them reduced by two hours. Labourers receive overtime pay for any work performed after three pm. Since the mawqif determines the working conditions and wages in the entire area, the new schedule applied to all of Saiss. Similarly, women who were employed in tobacco farming in Betit 
refused to accept the low pay offered to them and the employer was forced to offer a higher wage. The task performed most often by women in tobacco farming involves the drying of tobacco leaves. The new wage benefitted women employed in tobacco farms all over Betit. Unlike other Arab States, Morocco did not have the mass uprising against authoritarian regimes and large-scale protests of the Arab Spring in 2011. Nonetheless, it is important to recognise smaller victories won - such as collective organizing by agricultural labourers for higher pay - in Morocco against the backdrop of the Arab Spring in neighboring Arab States.

Women who work outside their home communities (through the mawqif) are more likely to work for farmers that they do not know and, according to some respondents, more likely to experience sexual harassment. Therefore, some women avoid working through the mawqif and prefer working within their communities for farmers that they or their husbands know. Many respondents simultaneously concurred that the labourers at the mawqif are predominantly women. This could perhaps be attributed to how desperate some women are for work, especially since many of them (about 45\%) were de facto or de jure heads of households. Women in the mawqif are hired in groups. For each group of women, two or three (usually male) labour supervisors are hired to ensure that the job is done. The mawqif operates in the labour-intensive areas of Betit and Sidi Slimane. In Ain Jemaa there is no mawqif. There are also no labour supervisors; both male and female labourers are hired locally. Employers in Ain Jemaa explained that women-only groups are preferred for harvesting legumes because they accept lower wages (by about 20 dirhams per person) compared to mixed-gender groups. As a result, employers prefer to hire women-only groups for harvesting legumes, which has perhaps consequently become a largely female task.

Labourers had access to diverse sources of information for finding work opportunities. Women mostly relied on neighbours, friends, mawqif, and middle men to access job opportunities. Men were relatively less dependent on mawqif and middle men. 
Men typically had stronger relations with landowners, who are largely men, for finding work. This reflects local norms related to gender segregation that limits interactions between men and women. As a result, men had wider access to sources of information about work opportunities. Some respondents reported that local coffee shops, for example, provided a large number of male labourers both with information about agricultural work as well as supplementary non-agricultural work. Many of the interviews with male labourers were indeed conducted in coffee shops.

To further understand working conditions, the study tried to understand the problems faced by male and female labourers at work as well as solutions suggested by them. About $31 \%$ of women respondents mentioned that they faced no problem at work as opposed to only $12 \%$ of men. Of course, this could simply reflect women's lower entitlement to paid labour, limited choices and weaker bargaining power rather than an absence of problems.

The major problems identified by male labourers included low wages, lack of work and poor working conditions, specifically lack of social protection and informality of work. Women also identified these as major problems. However, working under exhausting conditions (including working under the sun and starting work early in the morning), abusive supervisors (frequent insults) and sexual harassment ranked highest among problems faced by women. Female agricultural workers repeatedly reported that supervisors overseeing the work were especially disrespectful to women.

Both men and women complained that agricultural work is unstable and unreliable as a livelihood. Some women reported going to the mawqif at four am and still not being able to find work. Many female and male labourers emphasised they are at most able to work three days a week during the low season. Although low payments were reported more frequently as a problem by men, our interviews with employers revealed that women are more likely to experience late and reduced payments. Women are perceived to be secondary breadwinners 
(even when they are not) and have less bargaining power than men, and are therefore more likely to receive late and/or reduced pay.

As mentioned previously, women are frequently sexually harassed by labour supervisors or fellow male labourers. Both male employers and male labourers emphasised during interviews that women are typically blamed for being harassed and that the issue of sexual harassment is not gaining the attention it deserves. Women were expected to refuse men's sexual advances and accused of initiating them if they started complaining. Rarely were victims of sexual harassment sympathised with. Because women's access to work often depended on their tolerance of sexual harassment, they were rarely in a position to resist unwanted advances or to demand respect at work.

Like men, women frequently identified low wages as a problem. Tasks that are completed mostly by women are a double-edged sword. Women are hired more easily to complete them but only because they are more likely to accept lower wages. Women are also more likely to self-select to work in women-only groups, even while receiving lower wages, because they assume that they will be better protected from sexual harassment. At any given time, there are also more women labourers available for work than male labourers. This increased availability of women labourers might also bring down average wages for women. One farmer explained that out of 400 women in the mawqif, 100 women might not find work on a given day. This finding was confirmed by women labourers who mentioned going to the mawqif at the crack of dawn but being unable to find work.

Both men and women identified mechanization of agricultural work as a problem because it replaced tasks that had previously been performed manually, particularly by men. In turn, this sometimes led to men taking over tasks that had previously been performed by women, such as harvesting and weeding. This problem was more pronounced in Ain Jemaa, which is still the least mechanised area of the three case study areas but is - perhaps 
consequently - experiencing mechanization faster than Betit and Sidi Slimane. The tank sprayer is replacing backpack spraying and seeding and ploughing is becoming increasingly mechanised.

Solutions proposed by respondents for many of these problems included more job creation, expanded social protection from government and formalization of work. By formalization, respondents meant access to a stable income as well as social and medical insurance. Some of the solutions to sexual harassment proposed by respondents included gender-segregation at work and marriage of single women. Respondents explained that women who are married are less likely to experience harassment in the workplace. Although the same respondents emphasised that women should command respect at work regardless of their marital status, they remained unconvinced that this could realistically be accomplished for unattached women through, for example, more public education and awareness raising about women's rights and gender equality. The workers also reported having no formal and effective venue to voice their concerns. They proposed the creation of associations to lobby for better wages and working conditions.

\section{Coping strategies for seasonality of work}

Respondents were asked whether they experienced financial problems at any time of the year. Only $13 \%$ of women and $10 \%$ of men responded that they do not experience financial hardships during any time of year. Most men and women explained that the winter months were the leanest because there was very limited work available. Some labourers reported that they have financial problems throughout the year due to low wages and late payment of wages. Others mentioned experiencing financial hardship during the month of Ramadan and Eid al-Adha due to increased expenditures. 
Both men and women identified reducing spending and taking loans as the strategies most commonly used to deal with financial hardships. Credit from local grocery stores enabled many labourers to purchase household goods during lean times. Men had a wider range of coping mechanisms, including selling livestock, asking for advances from employers, and migration. Men also reported having better access to other non-agricultural work and more savings. Women reported activities such as selling snails and working as maids in middle-class homes as strategies for surviving lean periods. Men reported selling leftover crops from farms and working in construction to get through the lean season. Networks of family and friends were identified by both men and women as means to cope with financial hardships. Moving in with family and accessing loans and financial assistance from parents, brothers and children were identified as coping mechanisms by male and female labourers.

\section{Decision-making related to participating in agricultural wage work}

Eighty-one percent of male respondents and $77 \%$ of female respondents explained that they independently made decisions about participating in the agricultural wage sector.

Seventeen $\%$ of male respondents explained that they had been forced to work in the agricultural wage sector by their fathers. By comparison, only seven $\%$ of female respondents explained that they were forced into the agricultural wage sector. Twelve percent of male respondents and seven $\%$ of female respondents reported that they made the decision to work in agriculture willingly after discussions with their family members.

When asked about the reasons for participating in the agricultural wage sector, both male and female respondents most often cited poverty and a simple need for money. Young workers ( $16 \%$ of young women and $13 \%$ of young men) were more likely to mention a desire to leave school and gain independence as the reason for joining agricultural labour. Our 
findings resonate well with Bossenbroek et al. (2015) who noted that although youth in Saiss were motivated by different material and ideological goals than their parents, they continued to be interested in agriculture as an occupation and considered "modernity to be quite compatible with rurality" (Bossenbroek et al. 2015, 342).

Twenty-one percent of adult male respondents and $26 \%$ of young male respondents identified agriculture as the only occupation available to them and therefore as the main reason for working in the sector. Both women and men in all age groups mentioned wanting to help their families as a major reason for participating in the agricultural wage sector. This included helping parents and husbands in meeting household expenses. Similar familial problems were identified by all groups of male and female workers: sick parents; parental death, particularly the death of sole-breadwinning fathers; and family disputes, which often led to moving out of natal homes. Some women mentioned migrating into the Betit and Sidi Slimane regions to work in the agricultural wage sector without the knowledge of their husbands. Only a small number of adult women mentioned the death of their husbands and the need to provide for their families as a leading cause for working in the agricultural wage sector.

\section{Discussion and Conclusions}

This study reinforced some established findings about women and wage equity in agricultural work - that women are paid less than men for the same work across skill and labour-intensity levels - while identifying other issues - variations in pay and working conditions for different crops, different types of farms, and rain-fed and irrigated areas - that are not as well documented in the literature on gender and agricultural labour. These findings highlight the importance of focusing not just on creating more agricultural employment but also paying closer attention to issues of equity in wages and working conditions. 
Morocco has a long history both of framing national legislation to prevent discrimination against women and also of signing and ratifying international conventions on gender equality. For example, in 1979 Morocco ratified ILO Convention 100 (1951) on Equal Remuneration, and in 1963 it had ratified ILO Convention 111 (1958) on Discrimination in Respect of Employment and Occupation (International Trade Union Confederation (ITUC) 2009). Article 346 of the Labour Code enshrines the principle of equal pay for work of equal value. Labour inspectors are legally required to ensure compliance with the principle of equal remuneration and to encourage employers to apply that principle when setting wage levels. In 2006, the Moroccan government adopted a national strategy on gender equity and equality aimed at integrating the principle of equality between men and women in development policies and programs. Equal access for men and women to the labour market is one of the explicit objectives of that strategy. It is important to note that the strategy also stressed the need to combat sexist stereotypes and societal prejudice against women. In practice, these stereotypes are, as our findings from Saiss demonstrate, pervasive and often the major causes of discrimination faced by women.

Enforcing legislation that already exists in Morocco to ensure equal pay for women and protection against discrimination is an essential first step towards enabling women to benefit equitably with men from their agricultural labour contributions. Such enforcement must occur in the context of wider social development interventions such as improving health and literacy levels. Although it has been touted as an 'IMF success story,' Morocco's performance in a wide array of social and economic areas lags behind that of other 'lowermiddle income' countries in the UN Human Development Index. Morocco also lags significantly behind other Arab states, including its nearest neighbors Algeria and Tunisia, in life expectancy, literacy and per capita income (Davis 2006), and Moroccan women are almost twice as likely to be illiterate (60\%) as Moroccan men (35\%) (ITUC 2009). 
Findings from our research in Saiss revealed that young men were much more likely than young women to be coerced into agricultural work as a result of family poverty. Deeply entrenched gender ideologies in Morocco and elsewhere require men to provide for their families. Our findings highlight the importance of paying research and policy attention to issues of gendered vulnerability for both women and men. Taken together, our findings and those of others (see, for example, Baruah 2009) reflect the importance of probing issues of social and economic inequity not just for further validation of female disadvantage, convincing as the findings may sometimes be, but also for counter-intuitive findings that shed light upon the complexity and dynamism of gender relations.

Finally, our findings suggest that a deeper structural revalorization of the importance and necessity of the agricultural sector within Morocco, the Arab States, and the world at large, is also required so that agricultural labour is not perceived as an occupation of last resort. Taken together, such approaches have the potential contribute significantly to the economic, social, and political empowerment of agricultural labourers in Morocco and elsewhere.

\section{Acknowledgements}

The authors would also like to thank the respondents in Saiss and researchers at INRA who have contributed to the survey. The paper benefitted from feedback provided in a write-shop organised by the CGIAR Research Program on Policies, Institutions and Markets. This work was supported by the Consultative Group for International Agricultural Research (CGIAR) through Research Programs Wheat under Grant 100230 and Dryland Systems under Grant 100228.

\section{References}

Abdelali-Martini, M. 2011. Empowering Women in the Rural Labour Force with a Focus on Agricultural Employment in the Middle East and North Africa (MENA). Aleppo, Syria: International Centre for Agricultural Research in Dry Areas (ICARDA).

Abdelali-Martini, M., P. Goldey, G. Jones, and E. Bailey. 2003. "Towards a Feminization of Agricultural Labour in Northwest Syria.” The Journal of Peasant Studies 30(2): 7194. 
Assaad, R. 2004. Why Did Economic Liberalization Lead to Feminization of the Labour Force in Morocco and De-feminization in Egypt? Minneapolis: Humphrey Institute of Public Affairs.

Baruah, B. 2009. "Monitoring Progress towards Gender-Equitable Poverty Alleviation: The Tools of the Trade." Progress in Development Studies 9(3): 171-186.

Bossenbroek, L., J. D. van der Ploeg, and M. Zwarteveen. 2015. "Broken dreams? Youth experiences of agrarian change in Morocco's Saiss region." Cahiers Agricultures 24(6): 342-48.

Davis, D. K. 2006. "Neoliberalism, environmentalism, and agricultural restructuring in Morocco." The Geographical Journal 172(2): 88-105.

De Haas, Hein, and Aleida Van Rooij. 2010. "Migration as Emancipation? The Impact of Internal and International Migration on the Position of Women Left Behind in Rural Morocco." Oxford Development Studies 38(1): 43-62.

FAO. 2011. Women in Agriculture-Closing the gender gap for development. Rome: The Food and Agricultural Organization.

FAO. 2016. Morocco: Country Profile. Rome: The Food and Agricultural Organization.

Galié, Alessandra. 2013. "Empowering Women Farmers: The Case of Participatory Plant Breeding in Ten Syrian Households." Frontiers 34(1): 58-92.

ITUC. 2009. Internationally Recognized Core Labour Standards in Morocco: Report for the WTO General Council Review of the Trade Policies of Morocco. Geneva: International Trade Union Confederation.

Lapham, R. 1969. "Social Control in the Sais.” Anthropological Quarterly 42(3): 244-262.

Mills, M. B. 2003. "Gender and Inequality in the Global Labor Force.” Annual Review of Anthropology 32: 41-62.

Razavi, S. 2007. "Liberalisation and the Debates on Women's Access to Land." Third World Quarterly 28(8): 1479-1500.

Weichselbaumer, D., and R. Winter $\square$ Ebmer. 2005. "A Meta-Analysis of the International Gender Wage Gap.” Journal of Economic Surveys 19(3): 479-511. 
Table 1. Sex and age characteristics of survey respondents.

\begin{tabular}{|c|c|c|c|c|c|c|}
\hline \multirow[t]{2}{*}{ Sex } & & & \multicolumn{3}{|c|}{ District } & \multirow[t]{2}{*}{ Total } \\
\hline & & & Ain Jemaa & Betit & Sidi Slimane & \\
\hline \multirow[t]{3}{*}{ Women } & $\begin{array}{l}\text { Age } \\
\text { groups }\end{array}$ & $\begin{array}{l}\text { Youth } \\
\text { (below } \\
24 \text { years) }\end{array}$ & 0 & 10 & 15 & 25 \\
\hline & & $\begin{array}{l}24 \text { and } \\
\text { older }\end{array}$ & 10 & 39 & 113 & 162 \\
\hline & Total & & 10 & 49 & 128 & 187 \\
\hline \multirow[t]{6}{*}{ Men } & $\begin{array}{l}\text { Age } \\
\text { groups }\end{array}$ & $\begin{array}{l}\text { Youth } \\
\text { (below } \\
24 \text { ) }\end{array}$ & 3 & 12 & 23 & 38 \\
\hline & & $\begin{array}{l}24 \text { and } \\
\text { older }\end{array}$ & 16 & 83 & 91 & 190 \\
\hline & Total & & 19 & 95 & 114 & 228 \\
\hline & $\begin{array}{l}\text { Age } \\
\text { groups }\end{array}$ & $\begin{array}{l}\text { Youth } \\
\text { (below } \\
24 \text { ) }\end{array}$ & 3 & 22 & 38 & 63 \\
\hline & & $\begin{array}{l}24 \text { and } \\
\text { older }\end{array}$ & 26 & 122 & 204 & 352 \\
\hline & Total & & 29 & 144 & 242 & 415 \\
\hline
\end{tabular}


Table 2. Agricultural activities by gender.

\begin{tabular}{llll}
\hline Activities & Women & Men & Total \\
\hline Harvesting legumes \& fruits & 112 & 133 & 245 \\
\hline Weeding & 126 & 70 & 196 \\
\hline Planting \& seeding & 71 & 124 & 195 \\
\hline Harvesting onions \& potatoes & 57 & 74 & 131 \\
\hline Packing & 87 & 26 & 113 \\
\hline Thinning & 71 & 38 & 109 \\
\hline Transplanting onions & 51 & 45 & 96 \\
\hline Pruning & 17 & 50 & 67 \\
\hline Irrigation & 4 & 55 & 59 \\
\hline Pesticide application & 9 & 25 & 34 \\
\hline Grafting & 30 & 2 & 32 \\
\hline Sorting onions & 10 & 3 & 13 \\
\hline Fertilizing & 1 & 10 & 11 \\
\hline Supervising labourers & 2 & 6 & 8 \\
\hline
\end{tabular}


Figure 1. Case study areas (Ain Jemaa, Betit, and Sidi Slimane)

Figure 2. Youth and adult gender wage gaps for all daily labour activities reported.

Figure 3. Sex-disaggregated average pay for all age groups for all activities reported.

Figure 4. Average age of entry into agricultural work.

Figure 5. Gender wage gap and average pay in the three communities. 


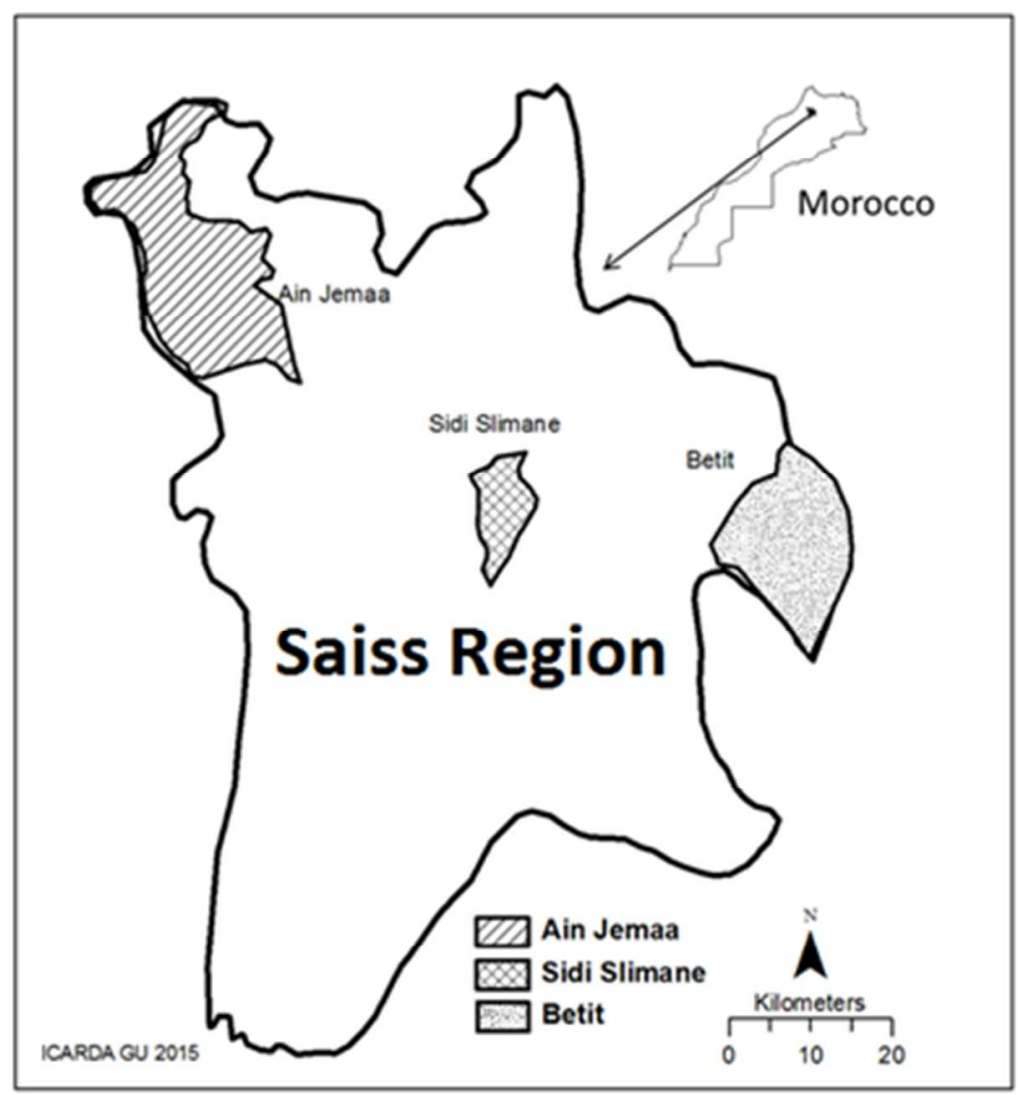

Case study areas (Ain Jemaa, Betit, and Sidi Slimane).

$70 \times 74 \mathrm{~mm}(144 \times 144$ DPI $)$ 


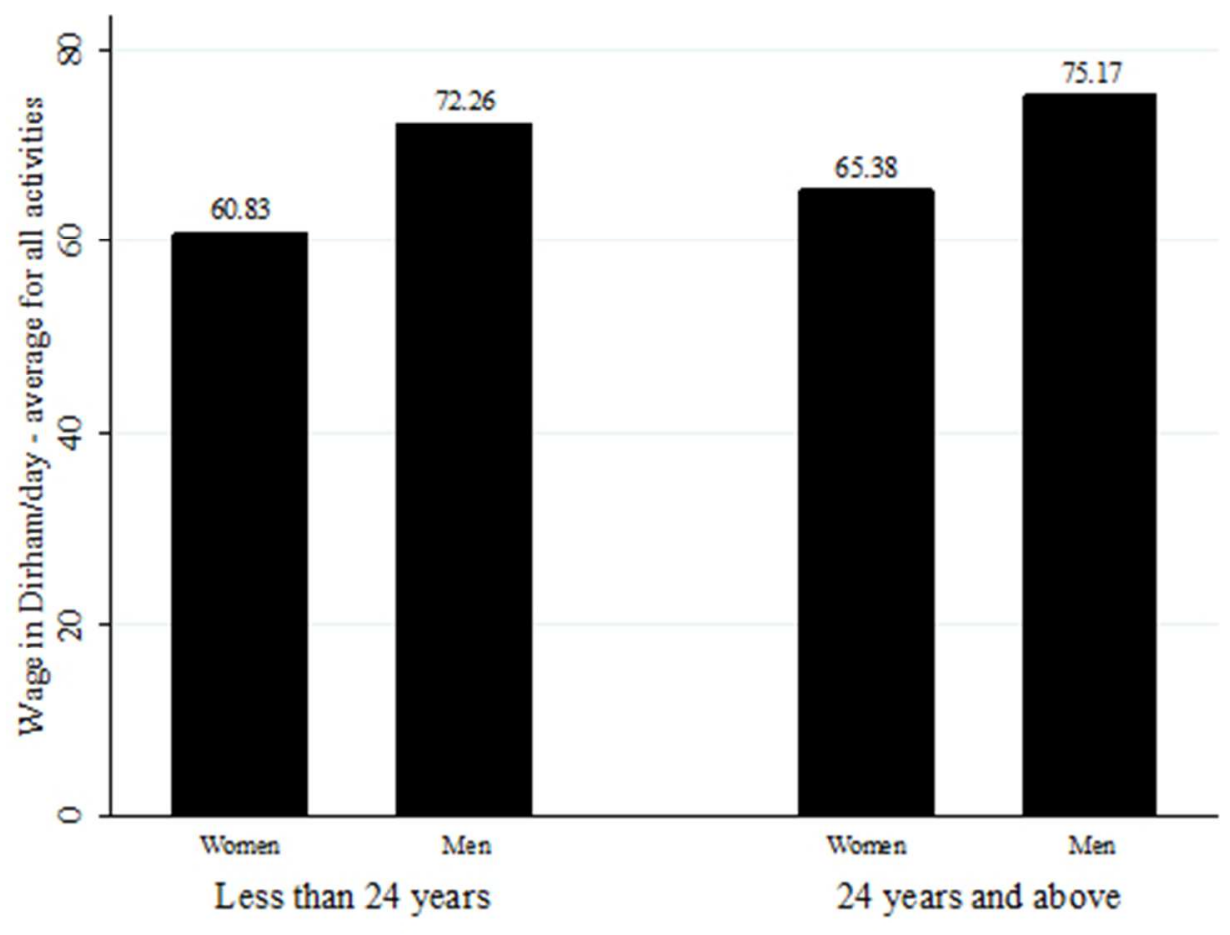

Youth and adult gender wage gaps for all daily labour activities reported $89 \times 74 \mathrm{~mm}(144 \times 144 \mathrm{DPI})$ 


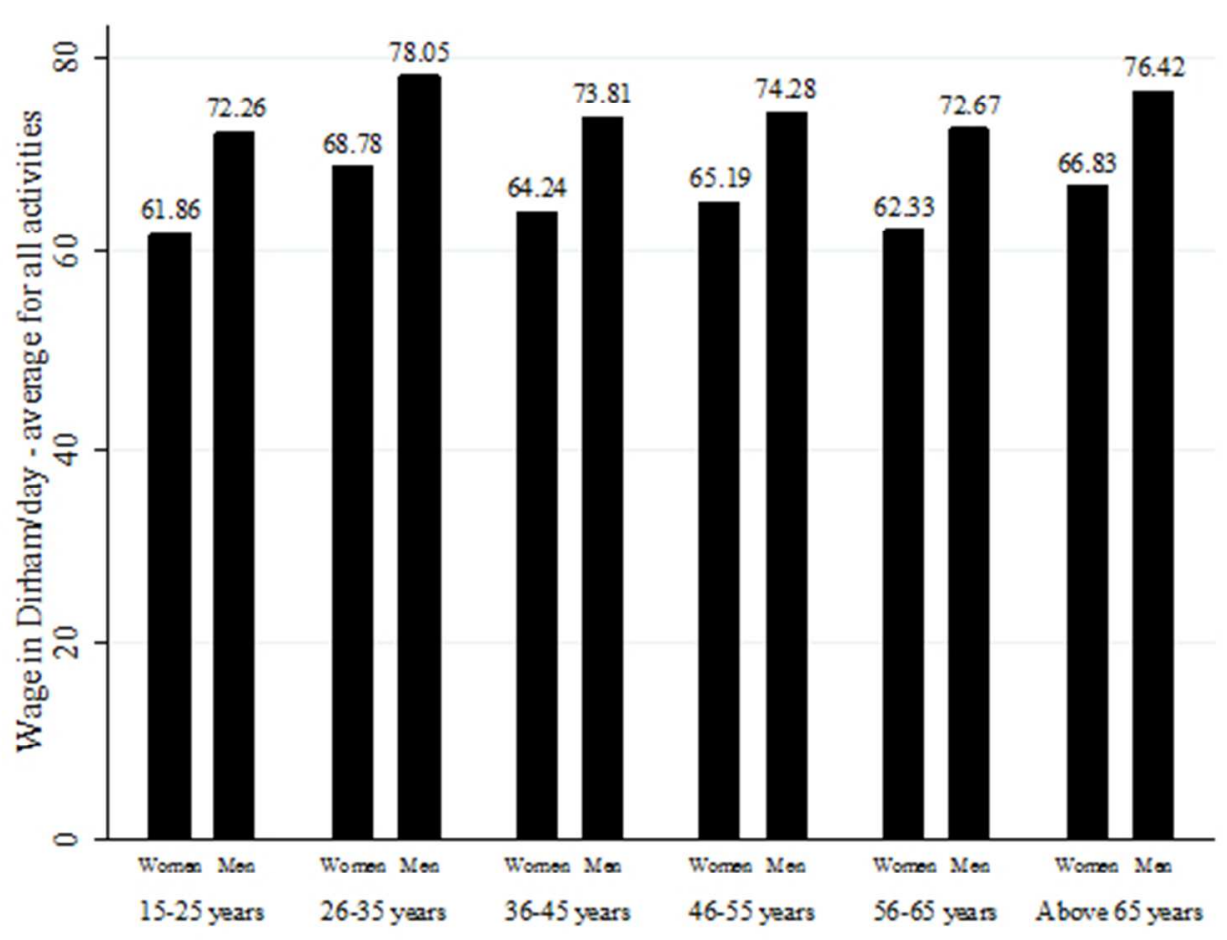

Sex-disaggregated average pay for all age groups for all activities reported $94 \times 74 \mathrm{~mm}(144 \times 144 \mathrm{DPI})$ 


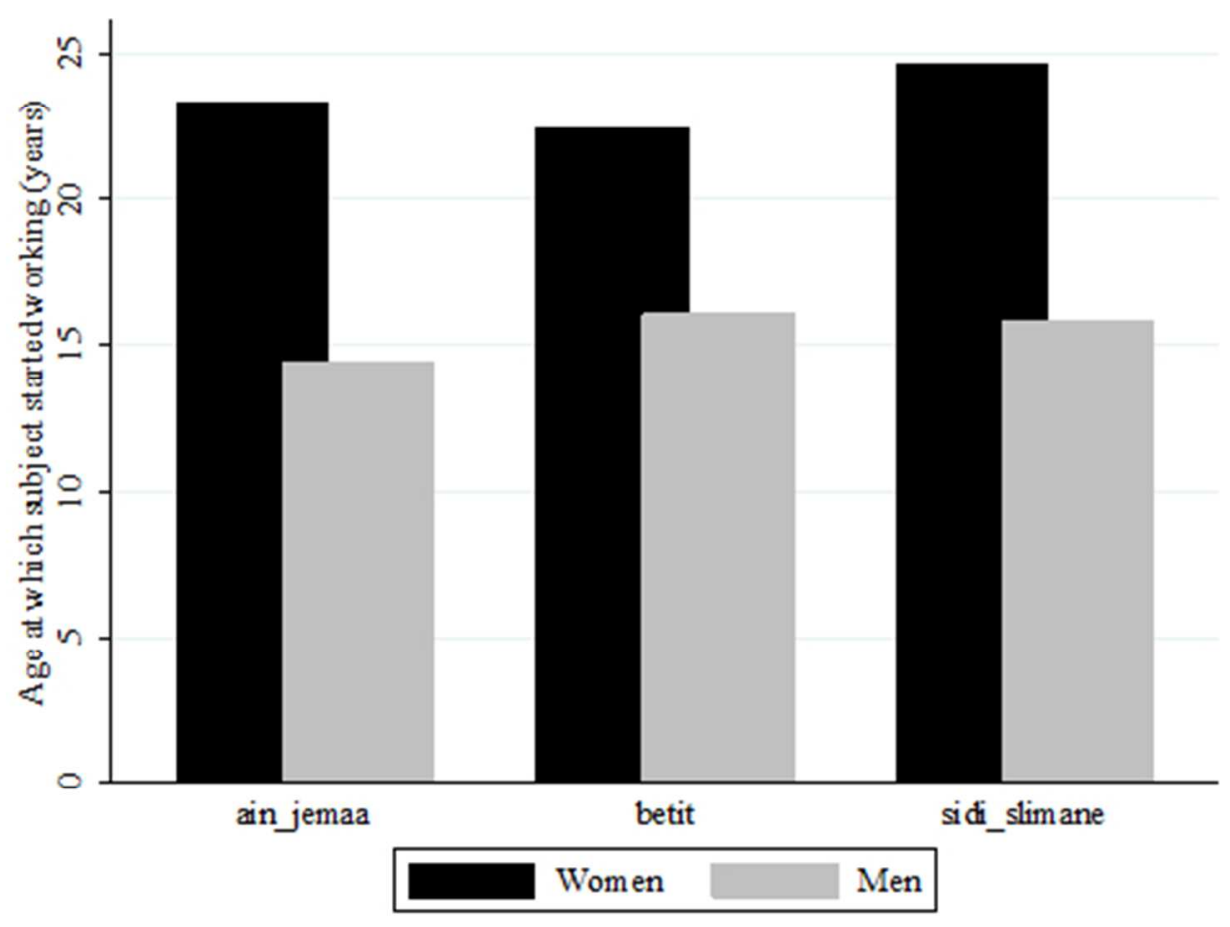

Average age of entry into agricultural work $89 \times 74 \mathrm{~mm}(144 \times 144$ DPI $)$ 


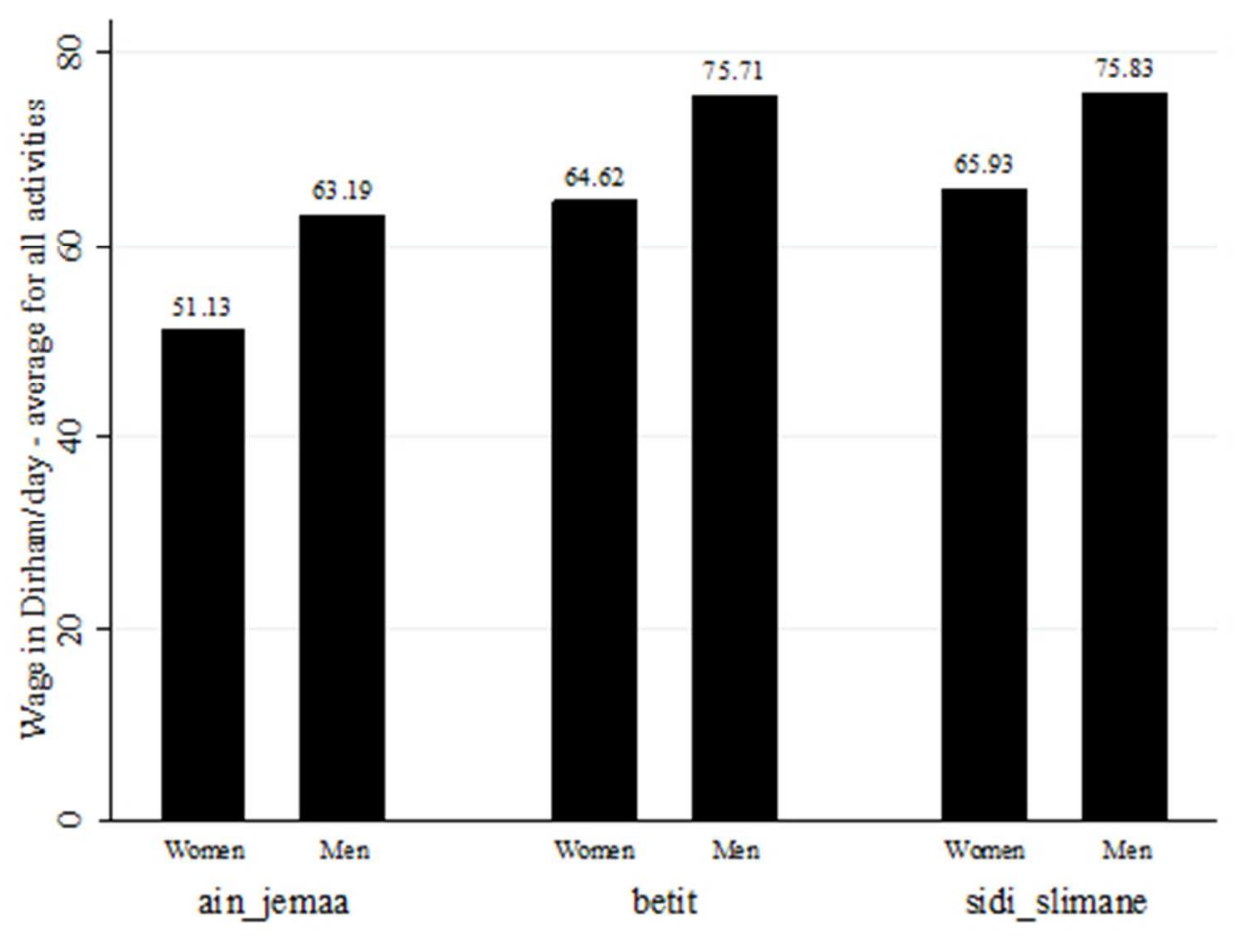

Gender wage gap and average pay in the three communities $88 \times 74 \mathrm{~mm}(144 \times 144$ DPI $)$ 


\section{Sex and age characteristics of survey respondents}

$203 \times 120 \mathrm{~mm}(144 \times 144$ DPI $)$ 


\begin{tabular}{llll}
\hline Activities & Wom en & Men & Total \\
\hline Harvesting legumes \& fruits & 112 & 133 & 245 \\
\hline Weeding & 126 & 70 & 196 \\
\hline Planting \& seeding & 71 & 124 & 195 \\
\hline Harvesting onions \& potatoes & 57 & 74 & 131 \\
\hline Packing & 87 & 26 & 113 \\
\hline Thinning & 71 & 38 & 109 \\
\hline Transplanting onions & 51 & 45 & 96 \\
\hline Pruning & 17 & 50 & 67 \\
\hline Irrigation & 4 & 55 & 59 \\
\hline Pesticide application & 9 & 25 & 34 \\
\hline Grafting & 30 & 2 & 32 \\
\hline Sorting onions & 10 & 3 & 13 \\
\hline Fertilizing & 1 & 10 & 11 \\
\hline Supervising labourers & 2 & 6 & 8 \\
\hline
\end{tabular}

Agricultural activities by gender $203 \times 114 \mathrm{~mm}(144 \times 144 \mathrm{DPI})$ 